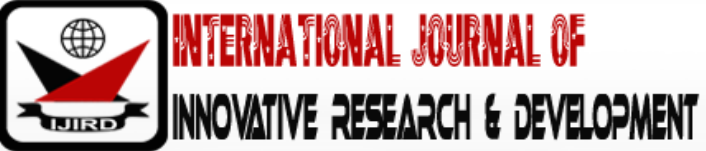

ISSN 2278 - 0211 (Online)

\section{Social Responsibility Theory of the Press: A Critique of Its Application and Constraints}

\author{
Paul, U. Obagwu \\ Ph.D. Researcher, Department of Mass Communication, Nasarawa State University, Keffi, Nigeria \\ Kabiru, M. Idris \\ Lecturer, Department of Mass Communication, Kano State Polytechnic, Nigeria
}

\begin{abstract}
:
Social Responsibility theory, an offshoot of Libertarian philosophy evolved following wide spread virulent criticisms that trailed the Libertarian Theory. Central to the evolution of social responsibility theory was the need for the press to reconcile freedom with obligations to the society in which it operates. Implied in this notion is for media practitioners to report truthful, comprehensive and accurate accounts and representative picture of events and occurrences to keep the people fully informed, untrammeled by other forces outside the ethical prescriptions. However, owing to self-serving interests arising from political and economic considerations in Nigeria as well as in most developing nations, the social responsibility theory has been advertently stripped of its core requirements for its emergence by governments and private media owners through subjective interpretation, leaving its twisted version to guide the press. Against this background, the paper presented a critical evaluation of the application and constraints of the theory in Nigeria. The paper found that the application of social responsibility of the media in Nigeria is defined by subjective political and economic interests with the later coming from private media owners. Public interest which is the primary consideration behind the theory is relegated into near annihilation. Arising from this standpoint, the paper concluded that the media has been too hamstrung to fully equip the people with the right information to assess the performances of the leaders, and to make informed decisions in the participatory quest for nation-building. The paper recommended that social responsibility should be seen by governments and other stakeholders as a duty to a journalist's conscience and a primary basis for the right of free expression without coercion or subterfuge to cow the media.
\end{abstract}

Keywords: Responsibility, accountability, press, fourth estate

\section{Introduction}

The relevance of the press in any society can be understood from the fact that information when we appreciate the centrality of information to socio-economic, political progress. A society suffers when there is mismanagement, hoarding or absence of credible information. Lack of right information breeds rumour networking with its counterproductive effect on the society.Rumour is powerful and its transmission is fast and strongly effective on many people - especially on those with very weak internal control mechanisms. Thus, right information shields the citizenry from rumour and keeps them better informed in a quest for national transformation. Credible and quality information by the press helps the people repose confidence not only in the media practitioners but also in the leaders promotes legitimacy for the government. Thus, the mass media are vital weapons whose roles are paramount in providing understanding of different political, social, economic and cultural systems of the society. They make events and ideas common knowledge, which is crucial to national-building.

There seems to be a continual unabated question revolving round the social responsibility of the media, particularly the press. Have the mass media truly been the cause of change in nation-building in Nigeria. Even though media scholars and politicians alike are all agreed that the media can aid rapid development, but they seem to be unsure as to whether the change or the development has been solely caused by the press. Is it the mass media that are slow and not awake to their responsibility or the system that hampers their effectiveness in this goal? This is a dialectical phenomenon worth knowing and to which, it is hoped, and this paper shall attempt to offer insight.

With the emergence of social responsibly theory, an offshoot of the Libertarian press theory, came the general acclaims that the burning issues that trail the Libertarian concept would be successfully laid to rest. But, somehow, it appears that social responsibility theory has ushered in greater challenges than what obtained in Libertarian theory. Most of the controversies surrounding social responsibility of the press are a function of divergent viewpoints among the trio of: the media practitioners, the owners and the government. There are perspective differences among the three forces regarding the practice and application of the theory. 
The mass media, particularly the press, is generally referred to as the Fourth Estate of the realms. This appellation crystallizes the crucial importance of the media to the society. Not only do the media provide information needed by the citizens to take informed decision and to make contributions to the overall societal growth, the media is expected to play a watchdog role, monitoring the activities of other arms of the government and communicating them to the people in a democratic society. Communication is an integral part of society upon which all activities within a society are based. In other words, the society and communication are intertwined. Thus, no society can exist without the role communication plays (Ravi, 2012).

Generally, the philosophy of social responsibility of the media is an extension of libertarian philosophy in that the media recognise their responsibility to resolve conflicts through discussion and to promote public opinion, private rights, and important social interests. Social responsibility is majorly premised on the ground that freedom carries concomitant obligations. While a responsible journalistic practice is a bulwark to societal progress, the press still carries the burden to ensure that their activities are guided by ethical requirements at all times. But the snag lies with the subjective interpretation and the obsession by the government as to what constitutes social responsibility of the press. To the government, the press is socially responsible when it nurtures their comfort zones; when it reports on issues that make them feel at ease rather than a form of reportage that rattles and keeps them on toes.

However, the society expects journalism to serve the interest of the people. To this end, it is expected that the media not only informs, but also educates. The society expects the media to play the role watchdog, leadership to the community, empowerment and many other emerging redeeming functions (Abubakar, 2012). These are basic cannons of journalistic functioning that emerged from the famous report by the Commission on Freedom of the press headed by Robert Hutchin in1947. But the fundamental questions to ask are: to whom should the press be responsible? Is the media responsibility to the owners or to the government or to the public?

Without prevarication however, Ravi (2012) clearly states that the media is obligated to the society that gives them freedom to operate. He emphasized that the media function as trustee of the public and must promote public interest always. But to what extent has this line of obligation and expectation of the media received practical fulfillment? This paper seeks to examine and unravel the true situation.

\section{Conceptual Clarification}

Perhaps, the seeming confusion in the meaning of certain terms as related to accountability and responsibility is at the root of the problem in situating what ought to be the media responsibility. To this end, it is expedient to look at the meanings of these terms to properly situate press responsibility.

\section{Accountability}

Within the context of journalism, accountability can be narrowly defined as liability or responsibility. With this understanding, it can be deduced that responsibility implicitly evolves from the term accountability. Accountability is indicative of a journalist being able to produce evidence to support what has been reported on (Melsande, 2009). From this conceptual view, accountability extends to overlap with the concept of Liability and responsibility.

A journalist is accountable in that he is held liable for the consequences of his reporting. Thus, liability in this case can be taken to signify being ethically or legally responsible for one's actions. From this standpoint, it can be understood that whether or not a journalist is to be considered being liable for his reporting logically hinges on the question of whether or not his profession entails a social responsibility.

The distinction between accountability and responsible as Melisande (2009) points can be understood this way: while accountability is often referred to as the manifestation of claims to responsibility, responsibility is the acknowledged obligation for action or behaviour within frameworks of roles and morals. In this sense, responsibility is the obligation for proper custody, care and safekeeping of a journalist's audience. This entails social responsibility, which Steev (2000) says specifically places a necessity for the journalist to keep society's interest as a top priority. In this connection, Hodges (1986) earlier avers that until it is determined what the press is responsible for doing, it cannot reasonably be demanded that the press give the account of it or improve its performance.

\section{The Notion of Social Responsibility of the Media}

In other to comprehend the field of Mass Communication as determinant factor in framing the path of society's development, it behooves on one to analyze the discourse of ethics in the public space. Social responsibility in journalism is by nature collaborative and collective. Thus, Steve (2000) says it inevitably bears an impact upon those receiving a piece of information from the media, which consequently makes the source - the journalist - responsible for its impact and consequences on others. The journalist as the communicator is therefore, intrinsically linked to its audience - hence the fundamental principle of the media obligation to fulfill public interest, which also lies at the basis of Social Responsibility Theory. The obligation imposed on the journalist by the Social responsibility theory is to provide fair, balanced, objective information on different sides of an issue, which empowers audiences to formulate their own judgments and increases levels of truthfulness in reporting.

Corroborating the view above, Melisanda (2009) argues that Social responsibility of the media from the perspective of a developing country like Nigeria entails that;

the mass media are expected to inform the citizenry of what goes on in the government, which in a way, keeps rules in check. Also, the media should be reporting on and prompting discussion of ideas, opinions and 
truths towards the end of social refinement; acting as a nation's bulletin board for information and mirroring the society and its people just the way they care, thus exposing the heroes and the villains (P.6)

From the notion of Social responsibility, Melisande (2009) posits that the press is accountable in four ways:

- To the audiences, to whom they own correct news reportage, analysis and editorializing.

- To the government to which they owe constructive criticism, a relay of popular opinion and adequate feedback from the populace;

- To the owner, to whom they owe the survival of the media organization as a business venture as well as a veritable source of education, enlightenment and entertainment;

- To themselves, to whom they owe fulfillment in their calling, satisfaction and an entire success story.

When any of these obligations of journalistic responsibilities is shunted, accountability is seriously dented which automatically gives rise to distorted responsibility as it is currently the case in Nigeria milieu.

Basically, responsibility of the media to the government as Ford (1991) avers, is in line with what Melisanda (2009) points out as we stated earlier. The media responsibility is to monitor and report truthfully the actions and inaction or activities of the government, commending and criticizing objectively where necessary. Responsibility of the media to the government entails holding the government accountable to the public and keeping her in checks against excesses or in the case of glaring failure

However, in Nigerian milieu, the successive governments seem to have their own versions of media social responsibility by redefining it in terms of what goes in tandem with protecting their failures and presenting favourable sides of their activities no matter how inaccurate or inimical the reports are to public interest. In trying to compel the media to give false picture of reality to the public, the actual expectation of the public from the media in fulfilling the notion of Social responsibility is grossly undermined and sidetracked. This thus constitutes a travesty of the concept of media responsibility.

\section{Emergence of Social Responsibility Theory}

The origin of social responsibility of the media can be traced back to a key landmark of the report produced by the Commission on the Freedom of the Press usually known as the Hutchins Commission. Ford (1991) says the project was requested in 1942 by the founder of Time Magazine, Henry Luce, at a time when it was believed First Amendment freedoms were being increasingly threatened by the rise of totalitarian regimes throughout the world. Black (2008) avers that the regimes felt that considerable check-mating measures must be place on the activities of the media against their perceived excessive freedom the Libertarian press theory ostensibly accorded the media. The libertarian theory is premised on the notion that man's wisdom will always ensure the victory of truth in the open battle with falsehood and so it was pointless to bridge the press in whatever guise. This as Idemili (2008) points out provoked anomalies and inconceivable excesses in media activities, manifesting in unwholesome lies, arrant misinformation character assassination, defamation and slanderous publication.

Against this background, totalitarian regimes were up in arms to bridle and gag the press. Alarmed by the indeterminacies of the extent the media could be clamped down with its attendant dire consequences on the society, Henry Luce felt something must be done to define the role and extent of the press freedom. The social responsibility theory gained prominence in the late forties against the backdrop of World War II. Henry Luce and Encyclopedia Britannica funded a Commission comprised a group of eminent scholars under the chairmanship of Robert Hutchin. The Commission published its first report titled: A Free and Responsible Press. Thus, the Hutchin's Commission was the first to enunciate in a coherent and systematic manner the social responsibility of the press. This report ever since has provided a blueprint for many subsequent studies on press responsibility and ethics.

The Commission which deliberated for four years came up with an encompassing prescription for the extent to which the press can exercise their freedom. The commission frowns at the basic premise of the libertarian theory that man's wisdom will ensure victory of the truth in the open battle with falsehood. Rather, it said that, not only is man a frail and often irrational being but the world which he must seek to understand is increasingly complex. Thus, the Commissioned resolved that a truthful, comprehensive account of the news was a yardstick for societal orderliness (Idemili, 2008).

To this end, Blevin 1997 in Melisande (2009:4) identifies five guidelines for a socially responsible press the Commission came up with in its report titled; A Free and Responsible Press:

- A truthful, comprehensive, and intelligent account of the day's events in a context which give them meaning;

- A forum for the exchange of comments and criticisms;

- The projection of a representative picture of the constituent groups in the society;

- The presentation and clarification of the goals and values of the society;

- Full access to the day's intelligence.

From the five guidelines enunciated above, emerged the theory of Social Responsibility of the Press. McQuail and Javan (2003) say the formal theory of

Social responsibility of the press came as the third of the four theories of the press namely, Authoritarian, Libertarian, Social Responsibility and Soviet. One pivotal characteristic of the theorists - Sietbert and Schramm - is an emphasis on the media's responsibility to use its powerful position to ensure appropriate delivery of information to audiences. Quoting Siebert (1956), Melisanda (2009. P. 5) avers that: 
The power and near monopoly of the media impose on them an obligation to be socially responsible, to see that all sides are fairly presented and that the public has enough information to decide and make inform decision for the general wellbeing and progress of the society

A careful perusal of both the Hutchins' report and the resultant theory put forth by Siebert and Schramm shows that the concept of public interest lies, albeit implicitly, at the heart of Social responsibility. This, consequently, highlights the crucial role of communications through the mass media in shaping societal processes. The media reports are crucial to the formation of public opinion and civic society movements, social and political development pattern, including more tangible processes such as unfurling of elections campaigns and their outcome.

\section{Social Responsibility and Freedom of the Press}

The mass media practitioners hold a major stake in every democratic society. Hardly can any society that lays claim to operating a democratic governance achieve its set goals without the involvement of the mass media. This explains why the press has been rightly described as the Fourth Estate of the Realm (in British concept). The concept implies that the journalists play as vital role in the governance of democracy as the other three branches - the Executive, the Legislature and the Judiciary. This concept is however not to be understood to mean a relationship of compromise. Rather, just as the first three arms of the government are in principle, interdependent, but in reality, checkmating each other, the press too, is expected to play both complementary roles at the same time a watchdog role over the three arms.

The journalists ought to act as the watchdog on behalf of the public on other centers of powers in society. In other words, the journalists are expected to stand apart often in an adversary stance. Affirming this view, Adeyanju (2005) says that the press is expected to play the role of an early warning system against major troubles that loom on the horizon of a nation or a community. Adeyanju stressed that when the press has the clear concept of its role and it is allowed to play the role effectively, there will be few problems of responsibility. However, Kadiri (2009) regrets that in the actual world of journalism, there seems to be multiple concepts and interpretation of responsibility of the media, a situation which attracts the contradictions surrounding responsibility of the media.

Fundamental to the conflicts interpretation of responsibility is government incessant attempts to manipulate the media into playing the role of mouthpiece rather than a watchdog role. In so doing, the governments often try to redefine the concept of press freedom using such subterfuge as national security or public safety. By this, the government and their agencies ensure that the journalist is only free to report issues to the public as long as their reports are not in conflict with national security or public interest. Ironically, in attempting to gag the journalists ostensibly to protect public interest, the interest of the public become endangered, or destroyed outright.

Freedom and responsibility of the media are closely related to each other. In spite of the close relationship between the concepts, responsibility of the media should not be used as a decoy to prevent the practitioner from reporting the unusual and the exceptional if such reports are of genuine public interest. Corroborating this view, Campell (2004) remarks that the freedom of the press is not merely a right of the publisher or journalists, but also the public's right to know all sides of an issue of public interest. He stressed that a free press is essential for democracy, adding that it was the reason freedom of the press had been established in most countries of the world through hard and difficult struggle.

In spite of the truism pertaining the freedom of the press as bulwark to democratic governance, Kadiri (2009) reports that political powers and governments in many countries - especially the developing countries - have tried to stifle and suppress the media using all kinds of subterfuge in order to achieve their preconceived objectives. According to Kadiri, various negative strategies including licensing, censorship and prohibition are often used to compel the press to operate within the confines of their (governments) version of the responsibility of the press.

Notwithstanding however, liberal thinkers still believe that the responsibility of the media should not be misconstrued to mean a device by which to gag or intimidate the journalists from carrying out their constitutionally prescribed roles in a democratic society. Press freedom and social responsibility represent a synergy meant to keep governments and their officials on toes for effective discharge of their obligations to the people - the public. To underscore the vital role of the media in a democratic society, Sarkar (1984) in Alanana (2003) quotes Indian's first Prime Minister Jawaharlal Nehru to have said that, "I would rather have a completely free press with all the dangers in the wrongful use of that freedom than a suppressed... press" (p.315).

The journalists act as a watchdog of government, as a gatekeeper, as well as purveyors of information meant to edify and keep the public fully informed about issues and occurrences. In other words, journalists should be alive to, and reflect interests and trends in the society. The responsibility of the media is to set agenda through accurate and truthful information for public debate by making inquiries on matters of public interest and publishing the findings for the public to be fully informed.

Information - truthful and accurate- is power; it is a conduit pipe for a meaningful socio-economic development and a catalyst for political transformation of democratic governance. Accurate and balanced information unlocks doors to new ideas, which in turn help to keep the citizenry better equipped to take informed decisions for the progress of a society. To function well in this direction, the public needs to trust the press by presenting verifiable, true, accurate and balanced information. In this vein, Dare and Merrill (2002) counsel the media to at all time act properly by ensuring that their reports are factual, balanced and accurate. The highest evidence of social responsibility of the press lies more with a total devotion to upholding public trust.

It may hold sways in some instances that journalists often betray the public trust by developing a negative attitude of good news is no news, resulting in the neglect of developmental activities or the positive sides of life, it must however be pointed out that the governments often major culprits in the convoluted interpretation responsibility. This 
consequently gives rise to adversarial relationship whereby the journalists are regarded as obstructive and a clog to sociopolitical stability in a society.

In their bid to report the truth about government failure as part of their watchdog role, the journalists are often seen as acting irresponsibly. This way, the government and the media see responsibility from crossing perspectives. To the government, the journalist acts responsibly and in line with public interest and national security when they support their failures; when the journalists cover the gross dereliction and inefficiency of the governments; when the truthful accounts, but which may be considered embarrassing, are either under-reported or suppressed.

The implication of this kind of reportage as Kehinde, Yinusa, Muhammed, and Raji (2015) point out, is that it impairs the effectiveness of the media as social institution of public trust. The reason being that this kind of negative journalistic practice leads to what Munagekar, (1996) in Kehinde et al (2015) calls tyranny of topicality. Kedinde et a; (2015) indict the beat system of news coverage as major culprit in the compromised journalistic practice where over familiarity often gives rise to compromise between the journalist and the government officials who are out to cover up their misdeeds and shortcomings leading to indulging the reporters to compromise.

Reporting public affairs, as Best (2005) argues, is more like advertising, portrayed rather mere background noise in the perception of the public. What happens at the centre of power is given an excessive, imbalanced publicity, contrary to the requirement of social responsibility which prescribes accurate, balanced and truthful dissemination of information to the public, and holding the government accountable through constructive criticism and depiction of their failures. This way, there is internal information imbalance against the hue of international information imbalance.

\section{Social Responsibility Theory: Application and Constraints}

The press is generally believed to have certain social obligations, but the extent to which these obligations are fulfilled remains a doubt in developing societies owning to several impediments. In the democratic system, the media is expected to regulate and direct its practice voluntarily without external coercion or subversion. While carrying out its task, the media is expected to be guided by good practices and management, with its social obligation to the public in sharp focus. This entails being objective and free from bias.

This forms the background to the concept of social responsibility of the press, which had evolved over a long period of time. Political free thinkers, proponents of libertarian views and those who fostered a democratic spirit like John Milton had a profound influence on the growth of the notion of social responsibility. The press is a child of liberty and freedom, free speech and expressions. Clearly, this has often been cited as a pattern and framework for many nations which resolved to opt for a free press. The United States of America particularly saw freedom of speech and expression as sacred phenomenon and so it was regarded non-negotiable. This provided an impetus to the movement towards press freedom, which the First Amendment fully encapsulated.

Prior to this time, the press was widely faulted for being socially irresponsible. The Commission thus exhorted the press of its obligation to project a representative picture of the constituent groups in society. Ford (1991) reports that the Commission charged the press to portray more faithfully the true condition and aspiration of ethnic and religious minorities and rural people. It urged the press to adopt affirmative action in this regard. It also addressed a broad array of questions dealing with the future of the press in a society out of which First Amendment to the US Constitution grew. It called for action by the press itself to correct some perceived excesses as characterized in the application of Libertarian Press Theory.

This admonition points out a striking difference between Libertarian and social responsibility theories. Affirming this stance, Ford (1991) remarks that though the difference between the two normative theories is subtle, but the subtlety notwithstanding, it is vitally important. While Libertarian press theory holds that the society would function better if the media were allowed to operate as they deemed fit and wanted, the social responsibility theory took exception to absolute freedom unattached with responsibility.

Thus, the social responsibility theory urges the media to do what the libertarian theory assumes they will doproviding a free market place of ideas. However,

Quoting Sandman et al, (1976), Ravi (2012) says the Commission insisted that a new era of public responsibility for the press had arrived. The interest of the public must be paramount and so the press should ensure that their performance be based on public service interest.

From the foregoing, it can be understood that the emerging theory from the libertarian- social responsibility- does not deny the rationality of man, although it puts far less confidence in it than the libertarian theory; but it does seem to deny that man is innately motivated to search for truth and to accept it as his guide. Under the social responsibility theory man is viewed not so much irrational as lethargic. He is capable of using his reason but he is loath to do so.

If man is to remain free, he must live by reason instead of accepting passively what he hears, sees or feels. Therefore, the alert elements of the community must goad him into the exercise of his reason. Without such goading man is not likely to be moved to seek the truth. The languor which keeps him from using his gift of reason extends to all public discussion. Man's aim is not to find truth but to satisfy his immediate needs and desires. To this, Akpoveta (2010) says it is the press that must be the more alert element and keep the public informed as he stressed that an informed populace is the cornerstone of democratic societies, the world over.

But given the convoluted interpretation of social responsibility of the media as given by most developing democracies in the world particularly in Nigeria, it stands to reason as to how the press can actually ensure an informed populace. Nigeria is one of the developing democracies where the notion of social responsibility theory has been twisted, leaving only a warp version and interpretation of the theory to guide media practices and reporting. What the governments and their agencies consider and see as social responsibility of the media is quite antithetical to the spirit and 
soul of the concept of social responsibility as envisioned both by the Hutchin's Commission report and the theory that emerged from the report.

To the government in Nigeria, responsibility of the media is not what keeps them on toes to discharge their responsibility creditably to the citizenry. It is not when the media engage them in constructive criticisms of their policies and misdeeds as advocated in the concept of social responsibility theory. It is not accurate reports about what governments or their agencies want to keep away from the knowledge of the public. Nigeria, as well as other developing democracies harps on social responsibility of the press in manner that actually leaves the press hamstrung. The press is only deemed socially responsible when its reports cushion their psyches in an apparent attempt to gag the media. With this as framework for defining the application of social responsibility theory, it is unrealistic for the press to successfully ensure the populace is well equipped with right information.

Many factors impede the application of social responsibility of the media, particularly in Nigeria. Adeyanju (2005) points out that besides governments and their agencies, the owner and managers of the media often determine which persons, which facts, which versions of these facts, should reach the public. Consequently, the tenet of social responsibility theory which makes it incumbent on the press to provide truthful, comprehensive and intelligent account of the day's event is subverted.

The media can only provide a forum for the exchange of comments and criticisms, providing a representative picture of the constituent groups in a society when governments and owners of media establishments genuinely key into, and accept the true version and application of social responsibility. Short of this expectation from the key deciders in a social system, it is impossible for the press to discharge the responsibility of presenting and clarifying the goals and values of society as well as providing full access to the day's intelligence as envision in the tenet of social responsibility theory.

Given the changed socio-political and economic circumstances in Nigeria. The question that a Nigerian journalist may grapple with is what should be the social responsibility of the media? Although the concept of social responsibility theory leaves no ambiguity as per the role of the media practitioner, but the social milieu in Nigeria, which is replete with counter forces, and which often dictate to the media their own version of social responsibility, has redefined the understanding of the concept.

For instance, the first requirement of social responsibility of the press as elucidated by the Hutchins Commission is to provide a truthful, comprehensive and intelligent account of the day's events in a context which gives meaning. By implication, this requirement demands that the press be accurate; identifying facts and reporting them for the citizenry well informed. This is also to ensure that there is an established fidelity to the public interest in news gathering and reporting.

However, Omenugha and Oji (2008) report that this requirement of social responsibility of the press has been turned upside down. Reporting a truthful and comprehensive account of the day from the view point of the government official, their agencies as well as some interested individuals and organizations, is the surest way to incurring the ire of the powers that be. The media by so doing is deemed irresponsible and working against the interest of the society. Consequently, what applies is nothing g but a travesty of social responsibility (Omenugha \& Oji, 2008).

Against the dictate of social responsibility theory, media outfit owners often tele guide newsgathering with a covert motive for political weapon; thereby distorting facts and suppressing the truth to meet the needs of the powerful. This has become the rule rather than exception. Affirming this view, Petterson and Wilkis (2005) aver that social responsibility of the press has been distorted to reflect a curious sort of objectivity; a kind of spurious reporting which glorifies half-truths, incompleteness, and incomprehensibility. To be objective and accurate in news reporting or interpretative journalistic writing seems like a big minefield riddled with dire repercussions.

The second requirement of the press in light of social responsibility theory is that the media should serve as forum for the exchange of comment and criticism. The undertone in this requirement is that the press should carry present views contrary to the viewpoints of the government their agencies, so long as the views express the general interest of the public. Important divergent viewpoints should be given attention and presented, and not merely those views which the government agrees with. This explains why former managing editor of The Lovisville Times, Norman Isaac (1953) posits that the one function the journalists have that supersedes everything is to convey truthful, accurate information about events in the society to the public. He emphasized that it was basically for this reason that the freedom of the press was given. Norman noted that keeping the society from knowing the truth about events in the society amounts to arrogance and backwardness. Freedom of information and people's right to information, are basic rights of the people. However, in Nigeria, a number of factors come in between freedom of information and people's right to the knowledge of the truth. Some of these impeding factors are discussed below.

\subsection{Nature of Nigeria Political Milieu}

Social responsibility theory makes provision for freedom of press without pre or post publication censorship, but at the same time charges the media on self-regulations. The theory lies between authoritarian theory and Libertarian theory because it gives total media freedom in one hand, and external control (ethical guidelines) in other hand.

The media is generally described as the catalyst to socio-economic development of any society. The unique role of the media in ensuring sustainable development is further accentuated by Akufeleye (2003) when he quoted Walter Williams, first Dean of the World's first school of Journalism at the University Missouri, Columbia, USA, describing the media as master key towards effective understanding of any society. He remarks that journalism transcends to heaven as a means of interconnection among the saints in heaven.

The basis of democracy, as erstwhile US president, Thomas Jefferson once said, is the opinion of the people, and the very first objective of any democratic society is to uphold this. It is the responsibility of the press to keep the wheel of 
public opinion well lubricated at all times. In this connection, the duty of the journalists is to use their positions, their powers, their skills, their clout, as collective instruments of education, mobilization and weapon of war against injustice, oppression and privation faced by the citizenry. Unless the journalists are given unfettered freedom, access and liberty to gather, process and publish accurate information for the citizen to be well informed about what transpires at the corridor of power, anything else is a negation to the spirit of social responsibility of the media. Thus, Akinfeleye (2003) argues that the imperative of media responsibility is based on journalistic autonomy and liberty to unhindered access to information necessary for society's progress.

Quiet often however, successful governments in Nigeria come up with convoluted notions of press responsibility as pretext to either shield off their gross dereliction or to cover up for their incompetence. In such situation, government officials often hastily resort to quoting or citing national security, or national interest as decoy to cow the media. Based on that, the media practitioners are wrongly portrayed as operating contrary to their avowed responsibility to the society.

Social responsibility of the media transcends the realm of government's comfort; it goes beyond feathering the nest of the government officials and their agencies to presenting facts in clear and unambiguous term to the people. This is what is implied in the tenets of social responsibility of the press as enunciated by Hutchin Commission. The interest of the public-not that of governments and their officials- must be paramount in the journalists' quest to fulfilling the objective of the social responsibility, by reflecting accuracy, balance and fairness in their professional performances. Unless the people - the public- are fully and accurately given a report of events happing in their socio-economic and political milieu, the media practitioners have not carried out their duty in light of the dictate of social responsibility.

Social responsibility of the press is better actualized when the interest of the public is ensured; when the expectation and aspirations of the people for full and accurate information and facts are ensconced in the performances of the practitioners. Perhaps, this explains why Merrill (1975) in Akinfeleye (2003) posits that true freedom of the press and their social obligations lie in the hearts of men and women, and not in the constitution or government. He contended that no law or court can do much to help in ensuring responsibility of the media. Impliedly, press freedom, responsibility or irresponsibility is determined by the concept of liberty of the press to perform their professional obligations to the people free from being gagged by the governments and their agencies.

Corroborating the stance above, Akinfeleye (2003) pungently pens this down for clarification:

A nation that is socially responsible both in concept, structure and ideology and governance, its press would tend to be responsible in their practice of the professional journalism. But on the other hand, a nation that is socially irresponsible, its journalists will be contaminated with irresponsible instincts and thus would practice irresponsible journalism, sensationalism, falsehood, bias, outright lies, propaganda journalism and unethical practices which, if not quickly checked may lead the Fourth Estate of the Realm to metamorphose into the Fourth Estate of the Wreck.

Akinfeleye's revealing prognosis above has added more steam to the earlier stance in this paper that the press can only behave responsibly and perform their professional callings as enshrined in their code of ethics only when the socioeconomic and political milieu is itself responsible and free of malfeasance. In other words, there is a mutually reinforcing relationship between the milieu in which media practitioners operate and the actual adherence to social responsibility of the media.

Poignantly however, rather than the governments create enabling environments to bolster the potency of the theory by allowing the practitioners to engage in productive search for information and communicate same to the public, they resort to war of attrition to reduce the effective application of social responsibility of the media. This gives rise to a situation where practitioners have to churn out half-truths to the public. A misinformed people are a deformed people, and a deformed society. For the media practitioners to truly reflect responsible practice in their callings, they must be degage to perform within the confines of ethical demands while the governments and other extraneous forces desist from prescribing self-serving conditions that are at variance with the fundamental tenets of social responsibility of the press.

Once they do what is right, there should naturally be no pressures from them to dictate or constantly "remind" the practitioners of the need to be responsible. This is a truism as their "reminder" is often a subterfuge to either gag the press or hide their incompetency. This is more so because, what the journalists do is a function of their societies, the world over. Thus, Siebert, Peterson and Schram in Folarin (1998) write that the press always takes the form and coloration of the social and political structures within which it operates. To see the difference between press systems in full perspective, the social systems in which the media practitioners operate must first be looked at or determined. And to see the social systems in their true coloration and relationship with the media, Akinfeleye (2003) says certain basis of belief and assumptions a society holds, the nature of the society and its relationship with the media and the nature of knowledge and truth must be assessed.

\subsection{Issues of Interpretation}

Social responsibility theory attempts to establish a relationship that exists or ought to exist between the media and the society. It is one of the normative theories which Siebert and Schramm (1956) in Folarin (1998) say their performances depend on the social milieu in which they operate. The manner or coloration a media system operates depends on the kind of political system in place. This suggests that the political structure of a particular society determines how the media will operate. Social responsibility accordingly tries to reconcile media independence with obligations to the society. But for the mass media practitioners to successfully fulfill these obligations depends on the nature of the sociopolitical milieu of a society; it determines the extent to which the press can meet these obligations. The society is a big shelter under which many factors abound to determine the role of the media in actualizing their obligations to the people. 


\subsection{Media Ownership Factor}

The Social responsibility theory of the press came into being as a result of pluralism in media ownership and content of the media, which created an uneasiness on the part of the public (Akinfeleye, 2003). The power of media owners then was much; owners determined which facts or opinions or what version of the story should reach the public.

This was contrary to the postulate of the Liberation theory of the press which advocated free and open market of ideas. Akinfelye (2003) observes that the influence of the media owner in deciding the editorial content is so overwhelming that editors no longer determined the newsworthiness of a story but it has been left for the media owners, advertisers, vendors and other considerations. This way, social responsibility in the eye of the media owners is what enhances their political, social or economic interests. Practitioners could be deemed irresponsible if they publish information that in the view of the owners is at variance with his subjective interests based on the factors pointed out above. For the media to be effective and credible in their obligations to being socially responsible to the society, they must be alignment of social obligations of the media with owners' interests. Effective interconnectivity between excellent professional performance and the objective and progressive interest of the owners is a sure recipe to effective Social responsibility of the media.

The press can hardly be responsible in their duty to the society in the face of perspective differences. Affirming this stance, Ajibade (2003) avers that press responsibility is a challenging issue in Nigeria because while the editor would be seeking for truth in news coverage, the publishers (owners) would be looking for profit and protection of political interest. Consequently, owners often dictate to the editor what he can do or cannot do; that he cannot use truth to buy newsprint or others materials to remain in business. Based on this challenge, it can therefore be understood that press freedom, and or press responsibility or irresponsibility are a function of what the owners decide based on their whims and caprices.

\subsection{National Interest in Nigeria}

As noted earlier, the socio-political ideology of a nation reflects the type of media practice obtained in that society. In Nigeria for instance, there has been so much hypes about the press being socially irresponsible to national interest. It is however clear that most of the times the media is indicted for being irresponsible, the indictment stems from a subjective interpretation. The media being the Fourth Estate of the realm is expected to watch and uncover the malfeasance at the corridors of power. Unfortunately, however, due to subjective interpretation, the media is harassed using the clichés of national interest when the media attempts to play their role of exposing or uncovering official misdeeds or dereliction. To the government official and their agencies, the media can only be seen to be responsible if they (practitioners) play along the lines of compromise by covering their misdeeds. This problem of subjective interpretation is at the root of so many instances of media indictment for being socially irresponsible in Nigeria.

National interest to all intents and purposes, does not include covering the misdeed of the government and other public office holders; it does not include slanting accurate report to portray only a side that is favourable to those in authorities and thereby denying the right of the public to know the truth. Rather, free and responsible media practice is about reporting the truth, accurate information in to equip the public to make informed decision and holding leaders accountable at all times. Responsible journalism is about ensuring a constructive criticism, to keep leaders from straying from their expected duties and obligations to the public. The highest level of social responsibility of the press is when the media practitioners, guided by their code of ethics constantly monitor the public officers and their activities and making the government accountable to the people. This is what being socially responsible entails. The media as tools for national development and sustainable democracy cannot be coerced into colluding with either the owners or the government officials to deprive the public of their right to know the truth about those elected or appointed into public offices. This is at variance with the principles of public interest.

\section{Social Responsibility: The Inverted Pyramid}

Media theorists and scholars are all agreed that the operation of the mass media is usually a reflection of the social milieu in which they are found. This presupposes that the social milieu in which the mass media operate determine the extent to which they contribute to socio-economic and political development which, by extension determines their impact on the overall nation -building. While agreeing with this thesis, Akingeleye (2003) conceptualizes the four Ps of Social responsibility of the press. He explained that the Four Ps represent the Press, the publishers the politicians and the people. Akinfelye argued that the four 'p's must work seriously together void of bitterness to achieve Social responsibility of the press. He stressed that the press can achieve nothing significantly in terms of impact on the nation - building if the other three - publishers, the politicians and people-are irresponsible in their acts.

For the mass media to operate responsibly in line with the dictate of Social responsibility theory, they must be a firm and committed cooperation among the other three Ps, they must first accept to be responsible in their conduct, and be seen to be responsible in all their actions. Allegations and accusations relating to irresponsibility against the media practitioners in Nigeria more often than not stem from media reports considered by the government "minefield" for social and political upheaval. But a critical view of such reports often shows that they were naturally benign and harmless presentation of facts and accurate information to the public. But given the attendant embarrassment the disclosures could cause those whose responsibility it is to do the right thing but failed, they resort to blackmailing the media to shelve the 
reports. If the journalist succumbs to the blackmail and censor the information; deprive the public of their right to know, the journalist is seen to be acting responsibly. Otherwise, the journalist is labeled irresponsible.

Peeved by the hypocrisy of the government, Babarinsa (2003) avers that Social responsibility of the press demands a symbiotic relationship among the Four State holders - the Executive, the Legislature, the Judiciary and indeed, the mass media. An understanding of Social responsibility from this perspective is basic to any systematic understanding of the extent to which the press adheres to the application of social responsibility. In a democratic society, it is expected that media practitioners should operate without the unusual restraints and censorships that characterized the authoritarian societies. The media in a liberal society is expected to move the nation towards the basic concept of rationality, freedom, liberty and open-market of ideas (Akinfeleye, 1988). This is in direct contrast to antiauthoritarian system of government in which media system moves towards absolute control, irrationality and censorship; where the right of people to know is lopped off.

The mass media being referred to as the Fourth Estate of the Realm, coming after the other three "Estates" implicitly indicates that the Fourth Estate shoulders the role of watch-dog to uncover and not to cover up corruption and related malfeasance of the other Estates. Media practitioners by this role are expected to monitor governance and make the other three Estates accountable to the people at all times. In essence, the media can only be Fourth Estate of the realm if they adhere strictly to their professional code of ethics at all times. But if otherwise, as it often the case in Nigeria, the result is an irredeemable damage to the corporate existence of the society it serves. This could wreck the society it is meant to protect.

\section{Conclusion}

Social responsibility theory of the media was envisioned and postulated a redemptive measure against the perceived excesses of Libertarianism. The theory aims at arming the press offer values to the society by providing accurate and truthful information to the society within the bounds of the Law. This is the media responsibility to the society. Even though the social system within which the media operates is a decisive determinant of how they operate, however, many developing nations, including Nigeria have subjected this belief to warp interpretation and accordingly used it as basis to justify intrusion and suppression of information from the media.

In a democratic society, the media is expected to regulate its practice voluntarily, guided by its code of ethics devoid of external coercion or subversion, while keeping its social obligation in sharp focus. This, to all intents and purposes formed the background to the evolution of Social Responsibility Theory encapsulated by Hutchins Commission, which gave birth to the theory. Underlining the notion of Social Responsibility is that the press, with obligations, is a child of liberty, freedom of speech and expression. This is a sacred and non-negotiable phenomenon. Social responsibility theory was not envisaged to be a weapon of censorship of the media by any factor through denial of access to information; rather it enjoins the media to report facts accurately within the ambits of responsibility and decorum.

But given the twisted interpretation of social responsibility of the media by leaders in Nigeria, which leaves only a warp version of the theory to guide media operations, truths, accuracy and factual reporting which the public needs, have become casualties, similar to what obtains in authoritarian theory. Successive governments and their agencies harp on social responsibility only in a parochial manner leaving the media hamstrung in their obligation to the society. Social responsibility of the media within the purview of Nigeria leaders receives a nod only when media reports are tele- guided to cushion their psyches, cover up their misdeeds or dereliction.

Consequently, application of social responsibility of the media in Nigeria has been defined by subjective political and economic interests with the later coming from private media owners. Public interest as primary consideration behind the theory is relegated to a point of annihilation. This leaves the people ill-equipped with the right information to assess the performances of the leaders, and to make informed decisions in the participatory quest for nation-building.

\section{Reference}

i. Akinfeleye, R.A )1990 Unumeduia Publishers.

Contemporary Issues in Mass Media Development and National security Lagos:

ii. Ajibadem K. (2003) Jailed for Life: A Reporter's Prison Notes. Ibadan Heinemann Educational Books.

iii. Babarinsa, D. (2003) House of War. Ibadan: Spectrum Books Limited.

iv. Akinfeleye, R.A. (2003) Fourth Estate of the Realm or Fourth Estate of the Wreck: Imperative of Social Responsibility of the press. An inaugural Lecture delivered on Wednesday May 14, 2003 University of Lagos.

v. Akpoveta, E.E. (2010) The Impact of the Mass Media in Restructuring the Nigerian political structure >in Oshiotse, A.O. (ed) Nigerian Stirling -Horden Encyclopedia of Mass Media and Communication: Social and Entrepreneurial Imperatives 3 (1) 11 - 31

vi. Omenugha, K.A, \& Oji. M (2008) 'News Commercialization, Ethics and Objectivity' in Journalism Practice in Nigeria: Strange Bedfellows? Estudos em Communicacao 3.1388

vii. Folarin, B. (1998) Issues in Applied Communication. Ibadan: Stirling - Horden Publisher

viii. Ford, N.B. (1991) Journalists as Bureaucrats Perceptions of Social Responsibility Media Roles in Local Emergency Planning International Journal of Mass Emergencies and Disasters 9 (1) 75 -87

ix. Hodges, L. W (1986) 'Defining Press Responsibility: A Functional Approach' in D. Elliot (ed) Responsible Journalism, Newbury Park: Sage Publication

x. Stevem H. (2000) 'Habermas Theory of Discourse and Ethics' Journal of Communication Inquiry 24 (1) 19-40

xi. Ravi, K. (2012) 'Media and Social Responsibility: A critical Perspective with Special Reference to Television, Academic Research International' 2 (1) 306-325 
xii. Kehinde, K. Yinusa, Am. Abdullataf, R. Abdu-Rasheed, L.S (2015), Constraints and Challenges of the Media in the Development of Nigeria Journal of Sustainable Development in Africa 17 (1)

xiii. Kadiri, K. (2009) Constraints and Challenges of Reporting Development News in the Nigerian Press. Journal of communication and Media Research, 2 (1) 125-146

xiv. Melisanda, M. (2009) Social Responsibility in the Media, Oxford: Centre for International Media Ethnics CIME

xv. Joy, B. (2008) An Informal Agenda for Media Ethicists, Petersburg: University of South Florida

xvi. Campell, V. (2004) Information Age Journalism: Journalism in an International Context. New York: Oxford University Press

xvii. Alanana, O. (2003) 'The Cultural Dimension of Africa's Development and Underdevelopment Paper Presented at the Cultural Studies Conference, Abuja'

xviii. Best, C. (2005), Development Communication and Empowerment in Nigeria: The Case of the Press 1999 - 2002. Unpublished Doctoral Dissertation, Department of English and Drama. Ahmadu Bello University, Zaria.

xix. Adeyanju, M.A. (2005) 'Development -related theories and their relevance to development communication and the operation of mass media in Nigeria. Unpublished Seminar Paper delivered at the University of Ibadan' 